maintained. Therefore, results presented in this study indicate that Heparin and heparin sulfate exert various influences on the reinforcement effects of osteoblast differentiation by BMP-2, particularly differences in activation time.

\title{
$\mathrm{P}$ - 24. パラタルバーの設定位置が厚さ弁別能に及ぼす影響
}

○麻生 千織·松木 貴彦·鱒見 進一 九歯大 · 欠損再構築

上顎部分床義歯装着の際，患者の口腔感覚にどのような影響が生じるか調査することを目的とし，パラタルバー設 定位置を基に 4 種の口蓋床を作製し，口蓋被覆部位の違いが厚さ弁別能に及ぼす影響について検討した。被験者は， 顎口腔機能に異常が認められない正常有歯顎者 10 名（男性 3 名，女性 7 名，平均年㱓 $26.6 \pm 3.03$ 歳）である. 実験 片として基準片と厚さを $0.2 \mathrm{~mm}$ ずつ薄くしたテスト片を用いた．基準片とテスト片をそれぞれ舌上に置き，舌と口 蓋間で厚さを認識してもらった。 そして基準片とテスト片の厚さが初めて異なると答えた時の差を弁別閾値とした. その結果, 全部口蓋床と比較して中・後パラタルバー部位被覆口蓋床は弁別閾值が低くなったが, 前パラタルバー部 位被覆口蓋床との間に有意差は認められなかった。そして 3 つの中で前パラタルバー部位被覆口蓋床が最手弁別能が 低く，中パラタルバー部位被覆口蓋床が高い傾向にあった.

\section{Effects of palatal bar position on thickness discrimination}

Chiori Asou, Takahiko Matsuki and Shin-ichi Masumi (Division of Occlusion and Maxillofacial Reconstruction, Kyushu Dental College)

The purpose of this study was to evaluate variation in thickness discrimination with changs in the position of a palatal bar. 10 normal subjects with no problems in oral function took part in this study. We made four kinds of experimental palatal plates. Three of them were based on a set position of the palatal bar: anterior (A), middle (M), posterior (P). Another one covered entirely by a whole hard plate (F). Test pieces with five thicknesses (3.0, 2.8, 2.6, 2.4 and $2.2 \mathrm{~mm}$ ) were used for the discrimination test. An experimental test piece was put on the subject's tongue and the thickness of it was offered for recognition. Next, another test piece was put on the subject's tongue and the subject questioned about us thickness. The subject was then asked about the difference in thickness between the two test pieces. There were a significant difference in the discriminative threshold for thickness between the $\mathrm{M}$ plate and the $\mathrm{F}$ plate, and the $\mathrm{P}$ plate and the $\mathrm{F}$ plate, but there were no significant difference between the $\mathrm{A}$ plate and the $\mathrm{F}$ plate. It can thus be concluded that the $\mathrm{A}$ plate allowed the lowest degree of discrimination and the $\mathrm{M}$ plate the highes.

\section{$\mathrm{P}-25.1$ 年次生テュートリアル教育の導入について}

○後藤 哲哉·栗野 秀慈·井上 博雅·瀬田 祐司·田中 敏子·森本 泰宏·山下 善弘·吉田 充広 九歯大・テュートリアル実施委員会 平成 17 年度より 1 年次生に対して『テュートリアルによるヒューマン・リレーションズ学習』が初めて本格的な テュートリアル教育として九州歯科大学に導入された。導入に際しては，国内外のテュートリアル教育に関するセミ ナーやワークショップに参加した教員を母体としたテュートリアル実施委員会を中心として準備が進められた。平成 17 年度は, 1 年前期の歯学概論の時間を 10 コマ 20 時間使い, この間 3 コマ ( 3 週) を 1 クールとし 3 クール行った. 学生は 12 の班に分けられ，班のメンバーは1クールが終了するごとに入れ替えた。また，テュータとしてのベ 36 名 の教員がそれぞれの班に割り当てられ，さらに統括者としてそれぞれのクール，2名のテュータリーダーを配置した。 今回は，1年次生の『テュートリアルによるヒューマン・リレーションズ学習』の詳細を紹介するとと屯に，同時に 行ったテュータならびに学生アンケートの結果を分析したので報告する. 今回のアンケートからはテュートリアル教 育その6のに対しては高い評価をテュータ, 学生双方から得られたものの, 時間配分への改善やテュータの介入の難 しさが指摘された。 